\title{
Değerler Eğitimi Dersine Yönelik Sınıf Eğitimi Öğretmen Adaylarının Görüşleri ${ }^{1}$
}

\author{
Vedat AKTEPE ${ }^{2}$, Elvan YALÇINKAYA ${ }^{3}$, Mevlüt GÜNDÜZ ${ }^{4}$ ve Murat \\ TEMUR $^{5}$
}

\section{Öz}

Bu çalışmada, Değerler Eğitimi dersini alan sınıf öğretmeni adaylarının derse ilişkin görüşlerinin belirlenmesi amaçlanmıştır. Araştırmada, nitel araştırma desenlerinden durum çalışması kullanılmıştır. Çalışma grubunu, 2017-2018 Eğitim-Öğretim yılı güz döneminde Nevșehir Hacı Bektaş Veli Üniversitesi Eğitim Fakültesi Sınıf Eğitimi 4. sınıfta öğrenim gören ve değerler eğitimi dersini alan, 5 kız ve 3 erkek olmak üzere, 8 ögretmen adayı oluşturmaktadır. Ders, ilk 6 hafta teorik ağırlıklı olmak üzere teorik ve uygulamalı olarak yürütülmüss, diğer 8 haftada ise öğretmen adaylarının yaparak yaşayarak öğrenmeyi esas alarak hazırlamış oldukları aktif öğretim yöntem ve tekniklerine dayalı etkinliklerle işlenmiştir. Dönem sonunda dersi tamamlayan ögretmen adaylarıyla odak grup görüşmesi yapılmıştır. Odak grup görüşmesinden elde edilen veriler içerik analizine tabi tutulmuştur. Elde edilen veriler çerçevesinde, öğretmen adayları değerler eğitiminin önemine ve toplumların geleceğindeki yerine vurgu yapmaktadırlar. Bununla birlikte değerler eğitimi dersinin teorik ve uygulamalı bir biçimde yürütülmesi gerektiğini ifade etmektedirler. Özellikle öğrenciyi aktif hale getirecek öğretim yöntem ve tekniklerinin kullanılması gerektiği sıklıkla vurgulanmaktadır. Öğretmenlik lisans programında bu dersin ilk yıllarda özellikle 1.sınıfta okutulmasını da önermeleri dikkate değer bir bulgudur. Elde edilen veriler doğrultusunda, değerler eğitimi dersini hem teorik hem uygulamalı olarak alan öğretmen adaylarının bu derse ve dersle ilgili süreçlere ilișkin önerileri, değerler eğitimi ile ilgilenen tüm eğitimcilere yol gösterebilir.

Anabtar Kelimeler: Öğretmen Adayı, Değerler, Değerler Eğitimi, Odak Grup Görüşmesi

\section{Views of the Pre-service Teachers Classroom Training or the Values Education (Value Training Course)}

\section{Abstract}

The purpose of this study is to determine the primary school teacher candidates' opinions who take a course of teaching values. The case study technique was used as the main method of the research. The research team consists of 8 teacher candidates ( 5 females and 3 male) and 4th year students of the Faculty of Education of Nevsehir Hachi Bektash Veli University 2017-2018 academic year. The first 6 weeks of the course were carried out theoretically while the rest 8 weeks were conducted practically which was based on active learning methods and techniques. As a result at the end of the course the focus group consisting of teacher candidates was organized and the data obtained from interviewing focus group was analyzed. Based on that data teacher candidates emphasize the importance of Value training course and its place in the future of society. Moreover they added that value training course should be conducted in a theoretical and practical way at the same time. According to the research this course is advised to be taught to the first year students. The results of this research can be used both who take Value training course and who teaches this course.

Key Words: Preservice Teacher, Values, Values Education, Focus Group Interview

\section{Atıf İçin / Please Cite As:}

Aktepe, V., Yalçınkaya, E., Gündüz, M. ve Temur, M. (2020). Değerler eğitimi dersine yönelik sınıf eğitimi öğretmen adaylarının görüşleri. Manas Sosyal Araştırmalar Dergisi, 9(2), 809-821.

\footnotetext{
${ }^{1}$ Bu makale Uluslararası Bilim ve Eğitim Kongresinde 23-25 Mart 2018 tarihinde sözlü bildiri olarak sunulmuştur.

2 Doç. Dr. - Nevşehir Hacı Bektaş Veli Üniversitesi Eğitim Fakültesi, vedataktepe@nevsehir.edu.tr ORCID: 0000-0001-5259-9340

${ }^{3}$ Doç. Dr. - Erciyes Üniversitesi Eğitim Fakültesi, elvanykaya@gmail.com

ORCID: 0000-0003-1838-0411

${ }^{4}$ Doç. Dr. - Süleyman Demirel Üniversitesi Eğitim Fakültesi, mevlutgunduz1981@hotmail.com ORCID: 0000-0001-5823-190X

5 Arş. Gör. - Nevşehir Hacı Bektaş Veli Üniversitesi Eğitim Fakültesi, murattemur@nevsehir.edu.tr ORCID: 0000-0001-8548-6342
} 


\section{Giriş}

Son y1llarda hem ülkemizde hem de dünyada toplumsal anlamda yaşanan değişim ve dönüşümün bir sonucu olarak temel insani değerlerin unutulmaya başlandığı görülmektedir. Değerlerin yaşatılması ve gelecek kuşaklara aktarılması hemen her dönemde önemini korumuş ve insanların sıklıkla üzerinde çalıştı̆̆ konular arasında yer almıştır. Toplumlar, kendi fertlerine milli değerlerin yanında evrensel değerlerin de öğretilmesini gerekli görmüştür. Geçmişten günümüze tüm toplumlar, iyi bir insan, iyi bir vatandaş, iyi bir toplum oluşturmak amacıyla değerler eğitimiyle ilgilenme ihtiyacı duymuşlardır. Birey, değerler eğitimi ile ilgili ilk kazanımlarını ailede edinmekte; okullarda bu eğitim daha sistematik bir biçimde gerçekleşmektedir.

Temel insani değerleri benimsemiş insanlar yetiştirmek toplum, aile ve okulun başlıca misyonlarından biridir (Ekşi, 2003, s.79). Örneğin Akbaş (2008a, s. 10) okulların bilişsel hedeflerinin yanında vatansever olmak, saygilı olmak, dürüst olmak ve adil olmak gibi birçok duyuşsal hedefi olduğunu belirtir. Değerler, toplumu oluşturan bireylere, nelerin önemli olduğunu, nelerin tercih edilmesi gerektiğini ve kısaca nasıl yaşanılması gerektiğini belirtir. Bununla birlikte değerler, bireylerin düşünce, davranış ve tutumlarını değiştirmede ve şekil vermede önemli bir role sahiptir. Ayrıca değerler, bireylerin insani algılarını arttırma ve değiştirmede, dünyaya bakış açılarını etkilemede büyük oranda etkilidir (Ulusoy ve Dilmaç, 2012, Önsöz Kismi).

Güngör'e göre (1993, s.19) değerler istek, tercih ve arzuları yansıtır, yani bir şeyin arzu edilebilir veya edilemez olduğu hakkındaki inançtır. Aydın (2010, s. 1) ise değer kavramını “... arzu edilebilen şey, olaylarla ilgili insan tutumu; ideal davranış biçimleri veya hayat amaçları hakkındaki inançlarımız, davranışlarımıza yön gösteren ölçüler...” olarak tanımlar. Pathania’ya (2011, s. 21) göre değer, insanın edindiği yaşam rehber ilkeleridir. İnsan yaşamına yön verir, hayatta mutlu olmasını ve hayatla barışı olmasını sağlar. Suriyachinnavar (2016, s. 34) ise değeri, standartlar, kurallar, kriterler, tutumlar, kurallar, istenen fikirler/inançlar olarak açıklamaktadır. Dolayısıyla değerler, hayata neşe, memnuniyet ve huzur getirmektedirler. Albayrak (2017, s. 30) değerlerin toplumsal yaşam için önemini şu şekilde ifade etmektedir:

\section{"Değerler, toplumsal yapımn olusturulması, düzenin sağlanması ve sürdürülmesinde önemli bir güce sabiptir. Toplum yaşantıst içerisinde oluşturulan ve yasallasstrrlan kanunlar toplumsal değerlerden güc alirken bunun yan sira toplumsal ilişkilerin düzenlenmesinde de değerler yer alir. Bir davranısın genel anlamda olumlu olarak kabul edilmesi, kabul görmüss olan toplumsal degerlerle uyum içinde olmasina bağhder. Ayrnca, toplumda nelerin

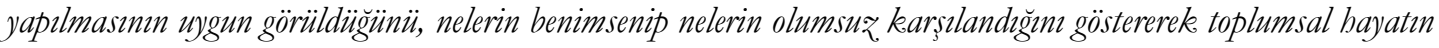 düreninin sağlanmasi ve sürdürülmesi için gerekli kontrolün oluşturulmasinda kilit unsurlardandr."}

Değerlerin sınıflandırılması konusunda hem ülkemizde hem de dünyada fikir birliği bulunmamaktadır. Schwarzt (1996, s. 122-123) değerleri "güç, başarı, hazc1lı, uyarılım, öz yönelim, evrensellik, iyilikseverlik, gelenek, uyum ve güvenlik" olmak üzere 10 grupta incelemektedir. Rokeach $(1973$, s. 28) ise, "amaç ve araç" değerler olarak sınıflandırır. Amaç değerleri; "rahat bir hayat, iç huzuru hırslı/istekli, gerçek sevgi, başarma hissi, ulusal güvenlik, barış içinde bir dünya, zevk, güzellikler dünyası, kurtuluş, eşitlik, öz sayg1, aile güvenliği, sosyal tanınma, özgürlük, gerçek dostluk, mutluluk, bilgelik/hikmet" olarak belirlemiştir. Araç değerler ise; "hırslı/istekli, hayal gücü kuvvetli, ufku geniş olma, bağımsızlık, kabiliyetli, entelektüel, neşeli, mantıklı, temiz, sevgi dolu/sevecen, cesaretli, itaatkâr, affedici, kibar, yardımsever, sorumlu, dürüst, Öz kontrol" gibi değerlerden oluşmaktadır.

Ülkemizde son yıllarda çalışmalarda sıkça kullanılan Akbaş (2004, s. 105) tarafından yapılan sınıflandırmada "geleneksel, demokratik, çalışma-iş, bilimsel ve temel" değer grupları belirlenmiştir. Aktepe ve Gündüz (2019, s. 78) ise değerleri belli başlıklar altında gruplayarak sinıflandırmıştır:

1. Milli değerler: Vatanseverlik, bağımsızlık, birlik ve kültürünü yaşatmak.

2. Dini değerler: Allaha inanmak, iffetli olmak, sadelik, tutumluluk, sabır, aileye bağllık, cömertlik, alçakgönüllülük ve güvenilirlik.

3. Evrensel değerler: Barış, mutluluk, temizlik, sağlık, sorumluluk, estetik, dürüstlük, özgürlük, sayg1, sevgi, adalet ve bilimsellik.

4. İnsani değerler: Anlayış, iyilik, duyarlılık, yardımseverlik, empati, fedakârlık, paylaşma, merhamet, hoşgörü ve vefalılik.

5. Bireysel değerler: Öz sayg1, öz güven, öz denetim, açık fikirlilik ve gayretli olmak

6. Toplumsal değerler: Misafirperverlik, dayanışma, işbirliği ve çalışkanlık. 
Akbaş (2008b, s. 340) değer eğitimini, demokratik bir toplumun başarısının temeli olarak görmektedir. Halstead ve Taylor, (2000, s. 170) ise pratikte, değerler eğitiminin, vatandaşlık eğitimi ve moral eğitimine odaklandığını belirtirler. Aynı zamanda, manevi, ahlaki, sosyal ve kültürel gelişim, karakter eğitimi, erdemler eğitimi, tutumlar ve kişisel niteliklerin gelişimi gibi güncel olarak kullanılan terimlerle yakından ilişsilidir (Halstead ve Taylor, 2000, s. 169).

Eğitim ve öğretim uygulamalarının sistemli ve düzenli olarak sürdürüldüğü mekânlar yani okullar, değer ögretiminin en etkili alanlarından birini oluşturmaktadır. Kültür aktarım sürecinde ele alınmış ya da alınmamış değerleri öğrencilere aktarmak, onları ortaya konan kurallar çerçevesinde disipline ederek ahlaki değer yargılarında ilerlemelere destek olmak ve çocukların karakter yapılarında olumlu bir etki sağlamak okulların önemli görevlerindedir (Şahin, 2017, s. 44). Değer ve eğitim kavramları karşıllklı olarak birbirlerini tamamlayan bir yapi içerisindedir. Değerlerin ya da eğitimin biri olmadan diğerini ele almak hem toplumsal hem de bireysel bakımdan farklı sorunları da beraberinde getirebileceğini söylemek mümkündür (Kart, 2017, s. 25). Türkiye Cumhuriyetinde Milli Eğitim Sistemi içerisinde yaklaşık son 16 yıldan beri farklı yoğunluklarda ve bilinçli olarak değerler eğitimi uygulanmaktadır. Söz konusu uygulamalar son 9 yildan beri yeni bir ivme içerisinde hareket etmektedir (Meydan, 2014, s. 93).

\section{Araştırmanın Amacı ve Önemi}

Toplumlar kendi yaşam biçimleri ve inanç şekillerine göre değer yargılarını oluşturmaktadır. Toplumlar tarafindan oluşturulan bu yargıların kuşaklar arası aktarımı ise eğitim yoluyla gerçekleşmektedir. $\mathrm{Bu}$ bakımdan değerlerin oluşturulmasında ve aktarılmasında eğitim önemli bir rol üstlenmektedir. Eğitim sayesinde, toplumlarda geçmiş ve geleceğe dair oluşan değer yargıları birbirini tamamlamaktadır (Özdemir, Boydak Ozan ve Akgün, 2017, s. 36). Kültürel ve ulusal açıdan anlamlı bir yere sahip olan değerler devletlerin izledikleri eğitim politikaları doğrultusunda vatandaşlara kazandırılmaya ve böylece ortak, geçerli ve birbirleri için güven arz eden değerler oluşturulmaya çalışılır. Bunun amacı geliş̧miş ve çağdaş ülkeler konumunda eğitim verebilmek ve insan yetiştirebilmektir. İşte bu aşamada bir insanın gelişim sürecinin en önemli basamağını oluşturan eğitim ve öğretimin birlikte verilmeye çalışıldığı okullar devreye girmektedir (Karataş ve Ergin, 2014, s. 34).

Ülkemizde özellikle son yıllarda değerler eğitiminin önemine ilişkin öğretmen adaylarıyla yapılan çalışmalar dikkat çekmektedir. Öztürk Demirbaş ve Çelikkaya (2012, s. 425) sosyal bilgiler öğretmen adaylarının programdaki değerlere ilişkin algısal farkındalıkları başıklı araştırmasında sosyal bilgiler öğretmen yetiştirme programında değerler eğitimine ilişkin bir dersin eklenmesini ön koşul olarak belirtmektedir. Kurtdede Fidan (2009, s. 17) ise öğretmen adaylarının değer öğretimine ilişkin görüşleri isimli araştırmasında öğretmen adaylarının değerler ve değer eğitimi konusunda eğitim almadıkları ve gerekli bilgilere sahip olmadıklarını ifade etmektedir. Bu çerçevede duyuşsal alan, özelde değerler ve eğitimi konusunda eğitim fakültelerinde öğretmen adaylarına değer eğitimi adı altında ders verilmesini önermektedir. Yine Oğuz (2012, s. 1315) öğretmen adaylarının değerler ve değerler eğitimine ilişkin görüşleri başlıklı araştırmasında öğretmen adaylarının değerleri kazanmasında değerle ilgili eğitimlerin verilebileceği, staj ve topluma hizmet uygulamaları gibi derslerin sayısının artırlması ve daha erken sınıflarda okutulması gerektiğini belirtmişlerdir. Nitekim değerler eğitiminin önemine vurgu yapan bu araştırmalar bir yana okutulmuş olan değerler eğitimi dersinin amaç, fayda, yöntem, öğrenme-öğretme süreç ve değerlendirmesine ilişkin önerilerin alındığı bir araştırmanın yapılmamış olması bakımından bu araştırma önem arz etmektedir.

Ailede başlayan okulda devam eden ve bireyin yaşamı boyunca süren değerler eğitimi süreci formal veya informal olarak verilmektedir. İlk olarak ailede verilen değerler eğitimi süreci önemlidir. Ancak bu süreçte en önemli rol eğitim kurumlarına aittir. Çünkü disiplinler arası bir şekilde sistemli ve düzenli olarak değerlerin çocuklara hissettirilmesi ve kazandırılması yönüyle eğitim kurumlarına dolayısıyla da eğitimcilere büyük sorumluluklar yüklemektedir. Bu bağlamda araştırmanın amacı doğrultusunda öğretmen adayları şu temalarda görüş bildirmişlerdir:

1. Değerler eğitimi dersinin amaçları

2. Değerler eğitimi dersinin önemi

3. Değerler eğitimi dersinin işlenişi/öğrenme-öğretme süreci

4. Değerler eğitimi dersinin faydasi

5. Değerler eğitimi dersinin yöntem-teknik/metodolojisi

6. Değerler eğitimi dersi ile ilgili öneriler 
Alanyazın incelendiğinde öğretmen adaylarının değerleri ve değerler eğitimi ile pek çok araştırmaya (Kurtdede Fidan, 2009; Oğuz, 2012; Öztürk Demirbaş ve Çelikkaya, 2012; Tural ve Gürgil, 2012) rastlanmıştır. Ancak okutulan değerler eğitimi dersinin değerlendirilmesine yönelik bir araştırmaya alan yazında rastlanmamıştır. Bu açıdan yapılan araştırma önem arz etmektedir. Nitekim öğretmen adaylarının, değerler eğitimi dersinin hedeflerini ifade edebilmesi, dersin faydasını, yöntemini, öğrenme-öğretme sürecini değerlendirebilmesi ve öneriler sunabilmesi önemlidir. Değerler eğitimi dersini alan öğretmen adaylarının davranışlarında örnek rol model olması ve her birinin birer değer eğitimcisi olması beklenmektedir. Bu bağlamda, öğretmen adaylarının değerler eğitimi dersine yönelik görüşlerinin tespit edilmesi önemli görülmektedir. Bu çalışmada, sınıf öğretmeni adaylarının değerler eğitimi dersine yönelik görüşlerinin belirlenmesi amaçlanmıştır.

\section{Yöntem}

\section{Araştırmanın Deseni}

Araştırmada nitel araştırma desenlerinden durum çalışması kullanılmıştır. Nitel araştırma desenlerinden ise durum çalışması kullanılmışıı. Durum çalışmaları hem nitel hem de nicel araştırma yaklaşımlarında kullanılabilir. Durum çalışmasının en önemli özelliği bir veya birkaç durumun derinlemesine araştırlmasıdır. Başka bir ifade ile ortam, süreç, olay gibi bir durumla ilgili etkenler bütüncül bir yaklaşımla araştırilır ve bu etkenlerin ilgili durumu nasıl etkiledikleri ve ondan nasıl etkilendikleri üzerinde durulur (Yıldırım ve Şimşek, 2016, s. 73).

Akar (2017, s. 174) ise durum çalışmasını "nitel araştırma desenlerine yakın bir araştırma yöntemi olup araştırmacıya, ilgili şahıslara, karar vericilere ya da kurumlara, bir durumla ilgili olarak ayrıntılı bilgi edinmede, bazen de kuramın doğruluğunu ve bağlama göre etkinliğini açıklama amaçlı olarak kullanılan araştırma yaklaşımlarından birisi” olarak tanımlamıştır. Bu çalışmada da öğretmen adaylarının değerler eğitimi dersine yönelik görüşlerinin belirlenebilmesi amacıyla durum çalışması kullanılmıştır.

\section{Çalışma Grubu}

Odak grup görüşmelerinde genellikle 4 ile 8 kişi arasında küçük bir grup insandan veri toplanır (Büyüköztürk, Çakmak, Akgün, Karadeniz ve Demirel, 2014, s. 152). Yine Krueger ve Casey'e (2000) göre de, araştırlacak konu, hizmet veya ürünle ilgili ortak bir deneyime sahip olmak şartıyla 6-8 arası kişinin odak grup görüşmesine katılması uygundur (Krueger ve Casey, 2000 Akt: Yıldırım ve Şimşek, 2016, s. 158). Bu nedenle araştırmanın çalışma grubunu, 2017-2018 Eğitim-Öğretim yllı güz döneminde bir devlet üniversitesinin sınıf eğitimi bölümü 4.sınıfında öğrenim gören ve Değerler Eğitimi dersini alan, 5 kız ve 3 erkek olmak üzere, 8 öğretmen adayı oluşturmaktadır. Veriler analiz edilirken katılımcilara K1, K2, K3... şeklinde kodlar verilerek analiz edilmiştir.

\section{Verilerin Toplanması}

Odak grup görüşmelerinde araştırmacı küçük bir gruptan bir dizi sorun hakkında düşünmelerini ister. Katılımcıların grup olarak, birbirlerinin soru ve cevaplarını kolayca duyabilecekleri bir şekilde oturmalarını ister. Grubun diğer üyeleri tarafından verilen cevapları duyduklarında genel olarak aslında söyleyeceklerinden başka ek yorumlarda bulunurlar. Görüş birliğinde olmaları istenen bir durum olmadığ1 gibi gerekli de değildir. Asıl hedef katılımcıların diğer grup üyelerinin yanıtlarını işiterek, bu yanıtlar üzerinden kendi görüşleri üzerinde kafa yormalarını sağlamaktır. Böylece insanların bir ya da birkaç konu hakkında gerçekten ne düşündüğü anlaşılmaya çalısıllır. Odak grup görüşmelerinde amaç tartışmak, problem çözme ya da karar almak değildir (Büyüköztürk, Çakmak, Akgün, Karadeniz ve Demirel, 2014, s. 152).

Odak grup görüşmelerinde, görüşmeye katılan bireylerin bakış açıları çerçevesinde farklı konularda derinlemesine bilgi elde edilebilir. Görüşmeye katılan bireylerin ön planda olduğu bu süreçte ortam, düşüncelerin rahatlıkla söylenebileceği şekilde ayarlanmalıdır. Özgürce fikirlerini ifade edebilen bireyler, grup dinamiği ve etkileşimi sayesinde birbirlerinin duygu ve düşüncelerini tetikler. Bu işlem sonucunda da özgün ve farklı fikirlere ulaşlır (Tunç ve Ertem, 2018, s. 1041).

Araştırmada veriler odak grup görüşmesi yoluyla elde edilmiştir Araştırmanın geçerlik-güvenirliği için iki uzman ve iki araştırmacının görüşü alınarak hazırlanan odak grup görüşme formunda sonda sorular sorulmuş, nitel araştırma yöntemine uygun olarak her bir tema için ayrı ayrı çözümlemeler yapılmıştır. Yine iki uzman ve iki araştırmacının görüşleri doğrultusunda gerekli düzeltmeler yapılmış ve asıl odak grup görüşmeleri gerçekleştirilmiştir. Bu bağlamda "değerler eğitimi” dersi kapsamında altı tema oluşturulmuş 
ve oluşturulan bu altı tema altı farklı odak grup oturumunda derslerden sonra gerçekleştirilmiştir. Araştırmacının konuyla ilgili aldığı eğitim, uzmanlığı ve nitel araştırma deneyimleri de güvenirliğ̣i destekleyen etkenlerdir. Öğretmen adayları gönüllülük çerçevesinde görüşmelere katılmışlardır. Görüşme formundaki sorular yarı yapılandırllmış görüşme yöntemine uygun olarak hazırlanmıştır. Odak grup görüşmesi esnasında katılımcıların etkilenmemesi ve yönlendirilmemesine dikkat edilmiş, araştırmanın geçerlik ve güvenirliğini sağlamaya özen gösterilmiştir. Ayrıca, odak grup görüşmeleri esnasında öğrencilerin verdikleri cevaplar onların izinleri dahilinde ses kayıt cihazına kaydedilmiştir. Sorular içerik özelliklerine göre öğrencilerin cevapları incelenmiş ve değerlendirilmiştir. Yine Ortalama 45-90 dakika süren odak grup oturumlarında araştırmacı tarafindan, öğrencilerin sözel olmayan unsurları da dikkate alınarak belli notlar alınmış soruları çözümleme esnasında göz önünde bulundurulmuştur.

\section{Verilerin Analizi}

Veriler, hem içerik analizi hem de betimsel analiz birlikte kullanılarak çözümlenmiştir. İçerik analizi, "Metin veya metinlerden oluşan bir kümenin içindeki belli kelimelerin veya kavramların varlığını belirlemeye yönelik yapılır. Araştırmacılar bu kelime ve kavramların varlığını, anlamlarını ve ilişkilerini belirler ve analiz ederek metindeki mesaja ilişkin çıkarımlarda bulunur." (Büyüköztürk, Çakmak, Akgün, Karadeniz ve Demirel, 2014, s. 240). İçerik analizinin ana amacı elde edilen verileri açıklayabilecek ilişki ve kavramlara ulaşmaktır. Bu amaçla da ulaşılan veriler önce kavramsallaştırılır. Daha sonra ise bu kavramsallaştırma sonucunda ortaya çıkan kavramlara göre mantıklı bir şekilde düzenlenir ve buna göre toplanan veriyi açıklayan temaların tespit edilmesi gerekir (Yıldırım ve Şimşek, 2016, s. 242). Betimsel analizde ise görüşleri çarpıcı biçimde yansıtmak amacıyla çok defa doğrudan alıntılara yer verilmiştir.

Öğretmen adayları ile yapılan odak görüşme sonucunda elde edilen veriler bilgisayar ortamına aktarılmıştır. Daha sonra bu veriler içerik analizine tabi tutulmuştur. Katılımcılara yöneltilen her bir soru tema olarak belirlenmiştir. Bu doğrultuda; "değerler eğitimi dersinin amaçları", "değerler eğitimi dersinin önemi”, “öğrenme-öğretme süreci”, "derste kullanılan yöntem ve teknikler”, "dersin yararları" ve "değerler eğitimi dersine yönelik öneriler” olarak 6 tema ortaya çıkmışır.

\section{Bulgular}

\section{Değerler Ĕ̆itimi Dersinin Amaçlarına İlişkin Bulgu ve Yorumlar}

Bu kısımda "Değerler eğitimi dersinin amaçları nelerdir?" sorusuna ilişkin bulgu ve yorumlara yer verilmiştir.

Tablo 1. Öğretmen Adaylarmm Değerler Eğitimi Dersinin Amaclarna İliskin Görüsleri

\begin{tabular}{lcc}
\hline \multicolumn{1}{c}{ Ifadeler } & $f$ & $\%$ \\
\hline Değerler Hakkında Bilgi Sahibi Olma & 6 & 16 \\
Değerlerin Nasıl Öğretileceğini Kavrama & 5 & 13 \\
Değerleri Davranışa Dönüştürme & 4 & 11 \\
Ders Programlarındaki Değerleri İnceleme & 4 & 11 \\
Değerler Eğitiminde Etkinliklerin Önemini Kavrama & 4 & 11 \\
Değerler Eğitiminde Proje Yapma & 3 & 8 \\
Eğitim Siteminde Değerlerin Yeri ve Önemini Kavrama & 3 & 8 \\
İyi Karakterli Bireyler Yetiştirme & 2 & 5 \\
Değerler Eğitimini Okul-Aile İşbirliği İle Yürütme & 2 & 5 \\
Değerler Eğitiminde Ders Planı Yapabilme & 1 & 3 \\
Toplumun Değer Yargilarını Bilme & 1 & 3 \\
İnsanlara Saygllı Olma & 1 & 3 \\
İnsanları Olduğu Gibi Kabul Etme & 1 & 3 \\
\hline
\end{tabular}

Tablo 1 incelendiğinde, öğretmen adaylarının değerler eğitimi dersinin amacı hakkındaki yorumları şu şekilde sıralanmaktadır: \%16'sı (6) değerler hakkında bilgi sahibi olma; \%13’ü (5) değerlerin nasıl öğretileceğini kavrama; \%11’i (4) değerleri davranışa dönüştürme; \%11’i (4) ders programlarındaki değerleri inceleme; \%11’i (4) değerler eğitiminde etkinliklerin önemini kavrama; \%8’i (3) değerler eğitiminde proje yapma; \%8’i (3) eğitim siteminde değerlerin yeri ve önemini kavrama; \%5’i (2) iyi karakterli bireyler yetiştirme; \%5’i (2) değerler eğitimini okul-aile işbirliği ile yürütme; \%3’ü ise değerler eğitiminde ders planı yapabilme; \%3’ü (1) toplumun değer yargilarını bilme; \%3’ü (1) insanlara sayg1lı olma; \%3’ü (1) insanları olduğu gibi kabul etmedir. 
Yukarıda yer alan verilerden, katılımcıların değerler eğitimi dersinin amaçlarına yönelik yorumlarının 'Değerler hakkında bilgi sahibi olma', 'Değerlerin nasıl öğretileceğini kavrama', 'Değerler eğitiminde etkinliklerin önemini kavrama', 'Değerleri davranışa dönüştürme' ve 'Ders programlarındaki değerleri inceleme' temaları üzerinde yoğunlaştı̆̆ görülmektedir. Çalışma kapsamında toplanan verilerden alınan doğrudan alıntıların bir kısmı aşağıda sıralanmıştır:

\begin{tabular}{|c|c|}
\hline Belitlenen Temalat & Aluntular \\
\hline Değerler Hakkında Bilgi Sahibi Olma & $\begin{array}{l}\text { "K1: Değerlerimizin ilk önce bilişsel boyutta ögrenilmesini sonra } \\
\text { duyuşsal olarak uygulanmast, içselleştirilmesini sağlar." } \\
\text { "K2, K4, K7, K8: Değerlerimizi bilme, içselleştirme" }\end{array}$ \\
\hline Değerlerin Nasıl Öğretileceğini Kavrama & $\begin{array}{l}\text { "K5: ...niye önemli olduğunun ve bu dersi ilkokul çağındaki } \\
\text { öğrencilere nasıl daha verimli ve iyi verebileceğimizi anlamamız } \\
\text { için okutulan bir derstir" } \\
\text { "K7: Değerlerin nasıl daha verimli ve iyi verebileceğini bilme" }\end{array}$ \\
\hline Değerleri Davranışa Dönüştürme & "K2, K5, K8: Günlük hayatlarında davranışa dönüştürme" \\
\hline Ders Programlarındaki Değerleri İnceleme & $\begin{array}{l}\text { "K2: İlkokul programında baz1 ders programlarında yer alan } \\
\text { değerleri inceleyebilme," }\end{array}$ \\
\hline Değerler Eğitiminde Etkinliklerin Önemini Kavrama & $\begin{array}{l}\text { "K1: Bu ders değerlerle ilgili yaratıc1 etkinlikler, projeler bulmaya } \\
\text { ve bu etkinlikleri duyuşsal boyutta nasıl uygulamam gerektiğini } \\
\text { öğreten bir derstir" }\end{array}$ \\
\hline Değerler Eğitiminde Proje Yapma & "K1, K2, K7: Değerler eğitimi ile ilgili projeler yapma" \\
\hline Eğitim Siteminde Değerlerin Yeri ve Önemini Kavrama & $\begin{array}{l}\text { "K1: Bu ders Türk Eğitim sisteminde değerlerin yerinin nerde } \\
\text { olduğunu bilmemize ve farkında olmamıza yardımcı oldu" } \\
\text { "K7: Türk Eğitim sisteminde değerlerin yerinin nerede olduğunu } \\
\text { bilme" } \\
\text { "K5, K7: Değerlerin insan yaşamındaki önemini kavrama" }\end{array}$ \\
\hline İyi Karakterli Bireyler Yetiştirme & "K4: İyi karakterli bireyler yetiştirme" \\
\hline Değerler Eğitimini Okul-Aile İşbirliği İle Yürütme & $\begin{array}{l}\text { "K4, K7: Ailede verilen değerlerle okulda verilen değerler uyum } \\
\text { sağlamalı ve birbirini tamamlamalıdır" }\end{array}$ \\
\hline Değerler Eğitiminde Ders Planı Yapabilme & "K7: Değerler eğitiminde ders planı yapabilme uygulayabilme" \\
\hline Toplumun Değer Yargılarını Bilme & $\begin{array}{l}\text { "K3: Bilindiği gibi değerler eğitiminin amaçları arasında toplumun } \\
\text { değer yargılarını bir sonra ki kuşağa aktarmak önemlidir." }\end{array}$ \\
\hline İnsanlara Saygilı Olma & $\begin{array}{l}\text { "K1: Bu yüzden insanların davranışlarına saygı göstermeyi ve } \\
\text { koşulsuz kabul etmeyi öğrendim." }\end{array}$ \\
\hline İnsanları Olduğu Gibi Kabul Etme & "K1: Her insanın farklı özelliklerinin bilme" \\
\hline
\end{tabular}

\section{Değerler Eğitimi Dersinin Önemine İlişkin Bulgu ve Yorumlar}

Bu başlık altında "Değerler eğitimi dersinin önemi nedir?" sorusu ile ilgili bulgu ve yorumlara yer verilmiştir.

Tablo 2. Öğretmen Adaylarmm Değerler Ë̆itimi Dersinin Önemine Illişkin Görïsleri

\begin{tabular}{lll}
\hline \multicolumn{1}{c}{ İfadeler } & $f$ & $\%$ \\
\hline Değerler Eğitimi Dersi Öğrencilerini Hayata Hazırlar & 5 & 18 \\
Kişilik Gelişimine Önemli Katkı Sağlar & 4 & 15 \\
Değer Eğitimini Uygulamalı Olarak Öğretir & 4 & 15 \\
Toplumla Uyum İçinde Yaşamayı Sağlar & 3 & 12 \\
Değerlerin Farkında Olmamızı Sağlar & 3 & 12 \\
Değerlerin Bilişsel ve Duyuşsal Anlamda İ̧selleştirilmesini Sağlar & 3 & 12 \\
Değerleri Nasıl Vermemiz Gerektiğini Öğretir & 2 & 8 \\
Toplumun Değer Yargısının Oluşumuna Katkı Sağlar & 2 & 8 \\
\hline
\end{tabular}

Değerler eğitimi dersinin önemine ilişkin verilerin yer aldığ Tablo 2 incelendiğinde: Katıllımcıların, \%18'inin (5) değerler eğitimi dersi öğrencilerini hayata hazırlar; \%15'inin (4) kişilik gelişimine önemli katk1 sağlar; \%15'inin (4) değer eğitimini uygulamalı olarak öğretir; \%12'sinin (3) toplumla uyum içinde yaşamayı sağlar; \%12'sinin (3) değerlerin farkında olmamızı sağlar; \%12'sinin (3) değerlerin bilişsel ve duyuşsal anlamda içselleştirilmesini sağlar; \%8'inin (2) değerleri nasıl vermemiz gerektiğini öğretir; \%8'inin (2) toplumun değer yargisının oluşumuna katkı sağlar şeklinde görüş belirttiği görülmektedir.

Bu kısımda adayların en fazla 'Değerler eğitimi dersi öğrencileri hayata hazırlar', 'Kişilik gelişimine katk1 sağlar' ve 'Değer eğitimini uygulamalı olarak öğretir' temaları üzerinde yoğunlaştığı görülmüştür. Çalışma kapsamında toplanan verilerden alınan doğrudan alıntıların bir kısmı aşağıda sıralanmıştır: 


\begin{tabular}{|c|c|}
\hline Belitlenen Temalat & Alintilar \\
\hline Değerler Eğitimi Dersi Öğrencilerini Hayata Hazırlar & $\begin{array}{l}\text { "K2: Sadece okulda değil, tüm hayatımız boyunca bu değerleri } \\
\text { hayatımıza katmalıyız" }\end{array}$ \\
\hline Kişilik Gelişimine Önemli Katk1 Sağlar & $\begin{array}{l}\text { "K5:Doğru kararlar vermemizi sağlar ve kişiliğimizi geliştirir" } \\
\text { "K6: Kişiliklerini oluşturur. Bu kişilik oluşturma sürecinde } \\
\text { verilmesi gereken en iyi ders değerler eğitimi dersidir" }\end{array}$ \\
\hline Değer Eğitimini Uygulamalı Olarak Öğretir & $\begin{array}{l}\text { "K1: Değerleri daha çok uygulamalı olarak öğreterek onların } \\
\text { topluma uyum sağlamasına yardımcı olur " }\end{array}$ \\
\hline Toplumla Uyum İçinde Yaşamayı Sağlar & "K1:Öğrencilerin toplumla uyum içinde yaşamalarını sağlar." \\
\hline Değerlerin Farkında Olmamızı Sağlar & $\begin{array}{l}\text { "K5: Değerlerimizi insanlara hatırlatmak ve yok olmamas1 için } \\
\text { büyük bir çaba harcamak gerekiyor" }\end{array}$ \\
\hline $\begin{array}{l}\text { Değerlerin Bilişsel ve Duyuşsal Anlamda İçselleştirilmesini } \\
\text { Sağlar }\end{array}$ & $\begin{array}{l}\text { "K1: Değerlerimizin ilk önce bilişsel boyutta öğrenilmesini sonra } \\
\text { duyuşsal olarak uygulanması, içselleştirilmesini sağlar." }\end{array}$ \\
\hline Değerleri Nasıl Vermemiz Gerektiğini Öğretir & "K1: Değerlerin nasıl verilmesi gerektiğini öğreten bir derstir" \\
\hline Toplumun Değer Yarg1sının Oluşumuna Katk1 Sağlar & $\begin{array}{l}\text { "K5: Bir toplumun değer sistemi ne kadar doğruysa o derece iyi bir } \\
\text { toplum olabilir" }\end{array}$ \\
\hline
\end{tabular}

\section{Değerler Eğitimi Dersinin Öğrenme-Öğretme Sürecine İlişkin Bulgu ve Yorumlar}

Çalışmanın bu kısmında 'Değerler eğitimi dersinin öğretme-öğrenme süreci nasıldır?' sorusuna ilişkin bulgu ve yorumlar yer almaktadır.

Tablo 3. Değerler Eğitimi Dersinin Öğretme-Ögrenme Sürecine Ilişkin Ögrretmen Adaylarmin Görüsleri

\begin{tabular}{lcc}
\hline \multicolumn{1}{c}{ Ífadeler } & $\boldsymbol{f}$ & $\%$ \\
\hline İlk Olarak Değer ve Değerler Eğitimi İle İlgili Kavramlar Teorik Olarak Verilir & 8 & $\% 30$ \\
Esas İtibariyle Değerler Eğitimi Sürecinde Etkinlikler Kullanılır ve Uygulamalı Olarak Ders Verilir & 8 & $\% 30$ \\
Değer Ĕgitimi Yaklaşımlarının Kullanılmasına Bu Süreçte Dikkat Edilir & 4 & $\% 15$ \\
Değerlerle İlgili Genel Bilgiler (Değerlerin Sınıllandırması, Özellikleri, Ders Programlarında & 3 & $\% 11$ \\
Değerlerin Yeri, Değerlerin Toplum Açısından Önemi, Öğretmenin Rolü, Aile İle İşbirliğinin & & \\
Önemi ve Değer Eğitimi Yaklaşımları) Teorik Olarak Öğretilir & 2 & $\% 7$ \\
Değerler Eğitimi Dersi Haftada 2 Saat Seçmeli Olarak Okutulan Bir Dönemlik Bir Derstir & 2 & $\% 7$ \\
Değer Eğitimi Sürecinin Sonunda Değerlendirme Yapılır & & $\%$ \\
\hline
\end{tabular}

Tablo 3 incelendiğinde değerler eğitimi dersinin öğrenme-öğretme sürecine yönelik öğretmen adaylarının görüşlerinin şu şekilde sıralandığı görülmektedir: \%30’u (8) ilk olarak değer ve değerler eğitimi ile ilgili kavramlar teorik olarak verilir, \%30'u (8) esas itibariyle değerler eğitimi sürecinde etkinlikler kullanılır ve uygulamalı olarak ders verilir, \%15’i (4) değer eğitimi yaklaşımlarının kullanılmasına bu süreçte dikkat edilir, \%11’i (3) değerlerle ilgili genel bilgiler (Değerlerin sınıflandırması, özellikleri, ders programlarında değerlerin yeri, değerlerin toplum açısından önemi, öğretmenin rolü, aile ile işbirliğinin önemi ve değer eğitimi yaklaşımları) teorik olarak öğretilir \%7'si (2) değerler eğitimi dersi haftada 2 saat seçmeli olarak okutulan bir dönemlik bir derstir, \%7'si (2) değer eğitimi sürecinin sonunda değerlendirme yapilir.

Tablo 3’te de görüleceği üzere, öğretmen adayları ‘ilk olarak değer ve değerler eğitimi ile ilgili kavramlar teorik olarak verilir' ve 'Esas itibariyle değerler eğitimi sürecinde etkinlikler kullanılır ve uygulamalı olarak ders verilir' temaları üzerine yoğunlaşmaktadır. Çalışma kapsamında toplanan verilerden alınan doğrudan alıntıların bir kısmı aşağıda sıralanmıştır:

\begin{tabular}{|c|c|}
\hline Belitlenen Temalar & Alintilar \\
\hline $\begin{array}{l}\text { İlk Olarak Değer ve Değerler Eğitimi İle İlgili Kavramlar Teorik } \\
\text { Olarak Verilir }\end{array}$ & $\begin{array}{l}\text { "K1:Bu derste öğretmen ilk } 6 \text { hafta öğretmen bize değerin ne } \\
\text { olduğunu, değerlerin neler olduğunu, değerlerin yaklaşımlarını, bu } \\
\text { değerlerde öğretmenlerin rollerini ve yeterliliklerini anlatır" }\end{array}$ \\
\hline $\begin{array}{l}\text { Esas İtibariyle Değerler Ĕgitimi Sürecinde Etkinlikler Kullanılır } \\
\text { ve Uygulamalı Olarak Ders Verilir }\end{array}$ & "K4: Slayt, video ve ek etkinlikler üzerinden değer anlatılır" \\
\hline $\begin{array}{l}\text { Değer Eğitimi Yaklaşımlarının Kullanılmasına Bu Süreçte Dikkat } \\
\text { Edilir }\end{array}$ & $\begin{array}{l}\text { "K1:Bu değerleri bizim seviyemizde değil ilkokuldan bir dersten } \\
\text { değerin geçtiği bir konunun kazanımını alarak öğrenci değerleri } \\
\text { değer eğitimi yaklaşımları kullanılarak anlatılır" }\end{array}$ \\
\hline $\begin{array}{l}\text { Değerlerle İlgili Genel Bilgiler (Değerlerin Sınıflandırması, } \\
\text { Özellikleri, Ders Programlarında Değerlerin Yeri, Değerlerin } \\
\text { Toplum Açısından Önemi, Öğretmenin Rolü, Aile İle İşbirliğinin } \\
\text { Önemi ve Değer Eğitimi Yaklaşımları) Teorik Olarak Ögretilir }\end{array}$ & $\begin{array}{l}\text { "K7: Değerlerin özelliklerini, değerlerin toplum açısından } \\
\text { önemini, değer eğitiminde öğretmenin rolü ve yeterlilikleri, aile ve } \\
\text { okulun bu konuda işbirliğini, değerler eğitimi yaklaşımlarını vb. } \\
\text { Konuları işleyerek ders hakkındaki genel bilgileri öğrendik" }\end{array}$ \\
\hline $\begin{array}{l}\text { Değerler Eğitimi Dersi Haftada } 2 \text { Saat Seçmeli Olarak Okutulan } \\
\text { Bir Dönemlik Bir Derstir }\end{array}$ & $\begin{array}{l}\text { "K2:Değerler eğitimi dersi seçmeli bir derstir. Bir dönemlik ve } \\
\text { haftada iki saat teorik olarak işlenir" }\end{array}$ \\
\hline Değer Eğitimi Sürecinin Sonunda Değerlendirme Yapılır & $\begin{array}{l}\text { "K5: Öğretmen ve diğer öğrenciler bu uygulama aşamasını izleyip } \\
\text { değerlendiriyor eksiklerini belirliyor." }\end{array}$ \\
\hline
\end{tabular}




\section{Değerler Eğitimi Dersinin Faydalarına İlişkin Bulgu ve Yorumlar}

Bu başlık altında ‘Değerler eğitimi dersinin faydaları nelerdir?’ sorusuna ilişkin bulgu ve yorumlar yer almaktadır.

Tablo 4. Değerler Eğgitimi Dersinin Faydalarna İlişkin Öğretmen Adaylarnm Görüsleri

\begin{tabular}{|c|c|c|}
\hline Ifadeler & $f$ & $\%$ \\
\hline Öğretmenlik Mesleğine Yönelik Kazanımlar & 5 & 31 \\
\hline Beceri Kazandırma & 4 & 25 \\
\hline Toplumsal Uyumla İlgili Kazanımlar & 4 & 25 \\
\hline Değerlerle İlgili Bilgi Sahibi Olma & 2 & 13 \\
\hline Duyuşsal Kazanımlar & 1 & 6 \\
\hline
\end{tabular}

Yukarıda yer alan veriler incelendiğinde öğretmen adaylarının \%31'inin (5) öğretmenlik mesleğine yönelik kazanımlar, \%25'inin (4) beceri kazandırma, \%25'inin (4) toplumsal uyumla ilgili kazanımlar, \%13’ünün (2) değerlerle ilgili bilgi sahibi olma \%6’sının (1) duyuşsal kazanımlar, temasına yöneldiği anlaşılmaktadır.

Odak grup görüşmesi sonucunda elde edilen verilerden, öğretmen adaylarının en fazla 'Beceri kazandırma', 'Toplumsal uyumla ilgili kazanımlar' ve 'Öğretmenlik mesleğine yönelik kazanımlar' temalarına yoğunlaştığı görülmektedir. Çalışma kapsamında toplanan verilerden alınan doğrudan alıntıların bir kısmı aşağıda sıralanmıștır:

\begin{tabular}{|c|c|}
\hline Belitlenen Temalat & Alintilar \\
\hline Öğretmenlik Mesleğine Yönelik Kazanımlar & $\begin{array}{l}\text { "K5: Değerler eğitimi konusunda değerlerin farkında, önemini } \\
\text { kavramış, ve bilinçli öğretmenlerin yanında bilinçli insanlarda } \\
\text { yetişiyor" } \\
\text { "K8: Bilincli öğretmenlerin vetismesi" }\end{array}$ \\
\hline Beceri Kazandırma & $\begin{array}{l}\text { "K3: Bir iş̧e başladığında çevresiyle iyi ilişskiler kurabilen, } \\
\text { yardımlaşmay seven, birey olarak kalacaktır" } \\
\text { "K4: İşirliği yapma" }\end{array}$ \\
\hline Toplumsal Uyumla İlgili Kazanımlar & $\begin{array}{l}\text { "K1: İnsanların birbirini anlamasına ve topluma uygun davranışlar } \\
\text { göstermesine yardımcı olur." }\end{array}$ \\
\hline Değerlerle İlgili Bilgi Sahibi Olma & "K1: Değerler ve özelliklerini bilme" \\
\hline Duyuşsal Kazanımlar & $\begin{array}{l}\text { "K1: Değerlerin bilişsel ve duyuşsal olarak öğrenmemize yardımcı } \\
\text { olur." }\end{array}$ \\
\hline
\end{tabular}

\section{Değerler Eğitimi Dersinde Kullanılacak Yöntem ve Tekniklere İlişkin Bulgu ve Yorumlar}

Bu kısımda 'Değerler eğitimi dersinde hangi yöntem ve teknikler kullanılmaktadır?' sorusu ile ilgili bulgu ve yorumlara yer verilecektir.

Tablo 5. Değerler Eğitimi Dersinde Kullanulan Yöntem ve Tekniklere Ilişkin Öğretmen Adaylarmun Görüsleri

\begin{tabular}{|c|c|c|}
\hline Iffadeler & $f$ & $\%$ \\
\hline Anlatım & 6 & 16 \\
\hline Sunu & 5 & 14 \\
\hline Drama & 4 & 11 \\
\hline Soru-Cevap & 4 & 11 \\
\hline Beyin Firtınası & 3 & 8 \\
\hline Örnek Olay & 3 & 8 \\
\hline Gösteri & 3 & 8 \\
\hline Proje & 2 & 7 \\
\hline Bireysel Çalışma & 2 & 7 \\
\hline Gezi-Gözlem & 2 & 7 \\
\hline Eğitsel Oyun & 1 & 3 \\
\hline
\end{tabular}

Öğretmen adaylarının, yöntem ve teknik bakımından , \%16 (6) anlatım, \%14 (5) sunu, \%11 (4) drama, $\% 11$ (4) soru-cevap, \%8 (3) beyin firtınas1, \%8 (3) örnek olay, \%8 (3) gösteri, \%7 (2) proje, \%7 (2) bireysel çalısma, \%7 (2) gezi-gözlem, \%3 (1) eğitsel oyun yöntem ve tekniklerine yöneldiği görülmüştür.

Ayrıca öğretmen adayları, \%22 (2) eylem yoluyla öğrenme, \%22 (2) değer telkini, \%22 (2) ahlaki muhakeme, \%22 (2) değer analizi ve \%12 (1) oranında değer açıklama yaklaşımına yönelmiştir. Değer eğitimi yaklaşımlarından 'Değer açıklama' dışında diğerlerinin neredeyse eşit düzeyde adaylar tarafindan benimsendiği, yöntem ve tekniklerden ise en çok 'Sunu', 'Drama', 'Anlatım' ve 'Soru-Cevap' tekniğinin benimsendiği anlaşılmıştır. 


\section{Değerler Eğitimi Dersi ile İlgili Katılımcıların Önerileri}

Bu başlık altında değerler eğitimi dersinin eğitim, öğretim veya değerlendirme sürecine ilişkin öğretmen adaylarının önerileri yer almaktadır.

Tablo 6. Değerler Ë̆gitimi Dersi İle İlgili Katullmcllarn Önerileri

\begin{tabular}{llcc}
\hline & \multicolumn{1}{c}{ Tema } & $f$ & $\%$ \\
\hline Lisans programındaki yeri ve & - & 3 & 10 \\
zamanının önemi & & 3 & 10 \\
\hline Yaklaşım, yöntem ve teknikler & Anlatım & 16 & 52 \\
& Aktif öğretim yöntem teknikleri & 2 & 6 \\
& Staj uygulama & 2 & 6 \\
& Rol model olma & 1 & 3 \\
\hline Öletişim & - & 3 & 10 \\
\hline Okunek projelerin incelenmesi & - & 1 & 3 \\
\hline
\end{tabular}

Tablo 6 incelendiğinde, öğretmen adaylarının lisans programındaki yeri ve zamanının önemine \% 10 (3), yaklaşım, yöntem ve tekniklere \% 77 (24), örnek projelerin incelenmesine \% 10 (3) ve okul-aile işbirliğine \% 3(1) oranında yöneldiği görülmüştür.

Öğretmen adaylarının söz konusu temalara ilişkin doğrudan alıntıların bir kısmı aşağıda yer alan tabloda sıralanmıştır.

\begin{tabular}{|c|c|}
\hline Belirlenen Tema & Alintilar \\
\hline $\begin{array}{l}\text { Lisans programındaki yeri ve } \\
\text { zamanının önemi }\end{array}$ & $\begin{array}{l}\text { "K-1 ve K-2:Bu ders üniversitenin ilk yıllarında verilmeye başlanılmalıdır." } \\
\text { "K-2:Özellikle üniversite son sınıf ögrencisine bu ders yük olmamalıdır." }\end{array}$ \\
\hline Yaklaşım, yöntem ve teknikler & $\begin{array}{l}\text { "K-7:Değerler eğitimine yönelik derslerde kullanılacak videolar, filmler, hikâyeler, örnek } \\
\text { olaylar üzerinde konuşarak. Hangilerinin kullanılıp hangilerinin kullanılmayacağ1 üzerinde } \\
\text { tartışma yaparak." } \\
\text { "K-4: Öğretmen rol model olmalı." }\end{array}$ \\
\hline Örnek projelerin incelenmesi & $\begin{array}{l}\text { “K-7:Sosyal sorumluluk projelerinin incelenmesi.” } \\
\text { “K-6:Ders süresince ülkedeki veya dünyadaki çeşitli sosyal sorumluluk projeleriyle bağlantı } \\
\text { kurulabilirdi. Ne tür değerlere yönelik çalışmalar yapıldığı incelenebilirdi.” } \\
\text { “K-8:Avrupa'daki değerler eğitimi çalışmaları incelenebilir. Örneğin Finlandiya da bu konuda } \\
\text { çok fazla çalışma yapılmış olabilir. Böylece Öğrenciler farklı bakış açılarını görerek ufkunu } \\
\text { genişletmiş, dünyaya tek bir gözlükten bakmamış olur.” }\end{array}$ \\
\hline Okul-aile işbirliği & "K-4:Değerler eğitiminde okul-aile işbirliği yapılmalı." \\
\hline
\end{tabular}

\section{Sonuç ve Öneriler}

Araştırmada, öğretmen adaylarının değerler eğitimi dersine ilişkin görüşleri nitel bir yaklaşımla belirlenmeye çalışılmıştır. Öğretmen adaylarının görüşleri 6 başlıkta incelenmiştir. Bunlar; "değerler eğitimi dersinin amaçları", "değerler eğitimi dersinin önemi", "öğrenme-öğretme süreci", "derste kullanılan yöntem ve teknikler", "dersin yararları" ve "değerler eğitimi dersine yönelik öneriler" başlıklarından (tema) oluşmaktadır.

Çalışmaya katılan öğretmen adaylarının araştırma bulgularından hareketle, değerler ve eğitimini önemli gördükleri sonucuna ulaşılmaktadır. Öğretmen adayları değerler eğitimi dersinin amaçlarını genel olarak; değerler hakkında bilgi sahibi olma, değerlerin nasıl öğretileceğini kavrama, değerleri davranışa dönüştürme, değerler eğitiminde etkinliklerin önemini kavrama, öğretim programlarındaki değerleri inceleme, proje yapma, eğitim sisteminde değerlerin yerini ve önemini kavrama, iyi karakterli bireyler yetiştirme ve değerler eğitimini okul-aile işbirliği ile yürütme olarak görmektedirler. Tay, Durmaz ve Şanal (2013, s.83) yaptı̆̆ araştırmada sosyal bilgiler dersinde değerler nasıl kazandırılmalıdır sorusuna 4, 5, 6 ve 7. sınıf öğrencileri en çok sırasıyla; faydaları, amacı ve değerlerin ne olduğu açıklanarak, sevdirerek ve benimseterek cevabını vermişlerdir. Bu anlamda değerler eğitimi dersinin genel amaçlarında ifade edilenlerle benzer özellikler göstermektedir.

Öğretmen adayları özellikle değerler eğitimi dersinin önemini; öğrencileri hayata hazırlama, kişilik gelişimine katkı sağlama ve değer eğitimini uygulamalı olarak öğretme, toplumla uyum içinde yaşamayı sağlama, değerlerin farkında olmayı sağlama, değerleri içselleştirme ve davranışa dönüştürme, değerleri nasıl öğretmemiz gerektiğini öğretme ve toplumun değer yargisının oluşumuna katkı sağlama bakımından önemli gördüklerini vurgulamaktadırlar. Değerler eğitimi dersinin önemini vurgulamak açısından Tural ve Gürgil (2012, s. 112) öğretmen adaylarının eğitim sürecinde lisans programlarında değer ve değerler 
eğitiminin önemi ve kazandırılması konusuna yer verilmesini önermiştir. Bu bağlamda tüm öğrenim süreci boyunca çeşitli dersler itibariyle, sorgulatıcı, katılımcı, etkileşimli dersler yürütülmesine önem verilmelidir. Bu aşamada en önemli görev rehber niteliğindeki eğitimcilere düşmektedir. Öğretmen adaylarının değerler ve değerler eğitimine katkı sunması açısından yine Öztürk Demirbaş ve Çelikkaya (2012, s. 424) öğretmen adaylarının ders programındaki değerlerden en çok bilimsellik, vatanseverlik ve saygı değerlerini önemsediklerini tespit etmişlerdir. Bu anlamda hayata öğrencilerin hazırlanmasında vatan sevgisinin önemi, bireylerinin saygı çerçevesinde toplumla uyumlu olması ve bilimselliği önemsemesi araştırma sonucunu desteklemektedir.

Öğretmen adayları değerler eğitimi dersinin faydalarını şu şekilde belirtmişlerdir; öğretmenlik mesleğine yönelik kazanımlar, beceri kazanımları, topluma uyumla ilgili kazanımlar, değerlerle ilgili bilgi sahibi olma kazanımları ve duyuşsal kazanımlar açısından değerler eğitimi dersinin faydalı olduğunu düşünmektedirler. Kurtdede Fidan (2009, s.16) öğretmen adayları değer öğretimi için en önemli şeyin değerleri yaşamak olduğunu, öğretmenlerin değer öğretiminde örnek kişi olamadıklarını ve sorunlar yaşandığını, medyanın değer öğretiminde okulun ve öğrenmenin etkisini azalttığını belirtmişlerdir. Bu anlamda değerler eğitiminde yaşanan sorunlardan kaynaklı olarak bu dersin zorunlu/seçmeli olarak okutulmasının elzem olduğu söylenebilir. Nitekim bu durum araştırma sonucunu da desteklemektedir.

Değerler eğitimi dersinin öğrenme-öğretme sürecine yönelik olarak öğretmen adayları değerler eğitimi dersinin hem teorik hem uygulamalı bir biçimde yürütülmesi gerektiğini ifade etmektedirler. Değerler eğitimi ile ilgili kavramlar teorik olarak (değer, değerler eğitimi, değerlerin sınıflandırması, özellikleri, ders programında değerlerin yeri, değerlerin toplum açısından önemi, ögretmenin rolü, aile ile işbirliğinin önemi ve değer eğitimi yaklaşımları) verilir. Öğrenme-öğretme sürecinde etkinlikler kullanılır. Oğuz (2012, s. 1319) Öğretmenlerin örnek rol model olması, sınıf içi etkinlikler, sosyal kültürel faaliyetler, örnek hayat hikayelerinden yararlanma ve ödev ve projelerle değerlerin öğrencilere kazandırılabileceğini belirtmektedir. $\mathrm{Bu}$ anlamda araştırmanın sonucunda da belirtildiği üzere değerler eğitiminde rol-model olma, okul-çevre ilişkisinin önemi, bireyin yakın çevresiyle bizzat yaşayarak değerleri öğrenmesine vurgu yapılmıştır. Bunun yanında öğrenciler dersin ölçme ve değerlendirme sürecine ilişkin dikkate değer görüşlere de sahiptirler. Öğretmen adayları, değer açıklama, değer telkini, ahlaki muhakeme, değer analizi ve eylem yoluyla öğrenme yaklaşımlarına dikkat çekmektedirler.

Öğrenciler değerler eğitimi dersinde yöntem ve teknik olarak anlatım, sunu, drama, soru-cevap, beyin firtınası, örnek olay, gösteri, proje, bireysel çalışma, gezi-gözlem ve eğitsel oyun gibi yöntem ve tekniklerin kullanılabileceğini düşünmektedirler. Katılımcıların değerler eğitimi dersini almış olmaları ve bu dersin aktif öğretim yöntem teknikleri kullanılarak yapılandırmacı yaklaşıma uygun yürütülmesinin de etkisinin olduğu düşünülmektedir. Aydın (2010, s. 6) değerler eğitimini önemsiyorsak, öğretimi ile ilgili, özel öğretim yöntem ve teknikleri geliştirmeliyiz. Bu çerçevede, "örnek olay incelemesi, dramatizasyon yöntemleri ve eğitsel oyunlar" değerler eğitiminde başarıyla kullanılabileceğini belirtmektedir. Bu anlamda araştırma sonucunu desteklemektedir.

Çalışmada yer alan her öğrenci kendi konu-kazanımı ile ilgili bilgiler toplayarak sınıfta proje sunumları gerçekleştirmişlerdir. Değerler eğitimi dersinin bu şekilde yürütülmesi, öğrencilerin değerler ve eğitiminin uygulamalı bir biçimde ve öğrenci merkezli yürütülmesi gerektiği düşüncesinin yerleşmesine neden olmuş olabilir. Değerler eğitimi dersinin eğitim fakültesi lisans programının ilk ylllarda özellikle 1.sınıfta okutulmasını da önermeleri dikkate değer bulunmuştur.

Araştırma sonuçlarından hareketle şu önerilerde bulunulabilir:

- Değerler eğitimi dersinin amaç, yarar ve önemi bu çalışmada ortaya konulmuştur. Bu bağlamda değerler eğitiminin ayrı bir ders olarak okutulması önerilir.

- Bir ders olarak okutulmasının yanı sıra öğretmen eğitiminde disiplinler arası bir yaklaşımla da değerler eğitimi verilmelidir.

- Öğretmen eğitiminde değerler ve eğitimine yönelik verilecek eğitim, öğrenci merkezli, yaparakyaşayarak öğrenmeyi ve aktif öğrenmeyi esas alacak biçimde tasarlanmalıdır.

- Proje tabanlı ögrenme esas alınabilir.

- Öğretmen adaylarına değerler eğitiminin etkili verilebilmesi için dersin önce teorik bilgilerle verilmesi daha sonra uygulamalı etkinlikler yoluyla yapılması önerilir. Değerler Eğitimi dersini hem teorik hem uygulamalı olarak alan ögrretmen adaylarının bu derse ve dersle ilgili süreçlere ilişkin önerileri, öğretmen eğitimi alanında çalışan kişi, kurum ve kuruluşlara yol gösterebilir. 


\section{Etik Beyan}

“Değerler Eğitimi Dersine Yönelik Sınıf Eğitimi Öğretmen Adaylarının Görüşleri” başlıklı çalışmanın yazım sürecinde bilimsel, etik ve alıntı kurallarına uyulmuş; toplanan veriler üzerinde herhangi bir tahrifat yapılmamış ve bu çalışma herhangi başka bir akademik yayın ortamına değerlendirme için gönderilmemiştir.

\section{Kaynakça}

Akbaş, O. (2004). Türk milli eğitim sisteminin duyussal amaçlarmm (değerlerinin) ilköğretim 8.sme ögrencilerinde gerç̧eklessme derecesinin değerlendirilmesi (Doktora Tezi). Gazi Üniversitesi Eğitim Bilimleri Enstitüsü, Ankara.

Akbaş, O. (2008a). Değer eğitimi akımlarına genel bir bakış. Değerler Eğitimi Dergisi, 16, 9-27.

Akbaş, O. (2008b). Sosyal bilgilerde değerler ve öğretimi. İçinde B. Tay ve A. Öcal (Edt.), Özel ögrretim yöntemleriyle sosyal bilgiler ögretimi (335-360). Ankara: Pegem Akademi Yayıncilık.

Aktepe, V. ve Gündüz, M. (2019). Değerler eğitimi. İçinde A. Uzunöz ve V. Aktepe (Edt.), Özel Öğretim Yöntemleri Cilt 1 (2. Baski) (71-103). Ankara: Pegem Akademi Yayıncilik.

Akar, H. (2017). Durum çalışması. İçinde A. Saban ve A. Ersoy (Edt.), Eğitimde nitel araştırma desenleri (139-177). Ankara: Anı Yayınclik.

Albayrak, F. (2017). Köktürk ve Uygur Dönemi eserlerindeki değerler ve bu değerler iliskin ögrretmen adaylarmin görïsleri (Doktora Tezi). Atatürk Üniversitesi Eğitim Bilimleri Enstitüsü, Erzurum. https://tez.yok.gov.tr sayfasından erişilmiş̧tir.

Aydın, M. Z. (2010). Okulda değerler eğitimi. Eğitime Bakıs, 6(18), 1-7. http://www.mehmetzekiaydin.com/makaleler/2010-34.pdf adresten erişilmiştir.

Büyüköztürk, Ş., Çakmak, E.K., Akgün, Ö.E., Karadeniz, Ş. ve Demirel, F. (2014). Bilimsel araştırma yöntemleri. Ankara: Pegem Akademi Yayıncilik.

Ekşi, H. (2003). Temel insani değerlerin kazandırılmasında bir yaklaşım: Karakter eğitimi programları. Değerler Eğitimi Dergisi, 1 (1), 79-96.

Güngör, E. (1993). Değerler psikolojisi. Amsterdam: Hollanda Türk Akademisyenler Birliği Vakfi Yay. No:8.

Halstead, J. M. ve Taylor, M. J. (2000). Learning and teaching about values: A revien of recent researcb. Cambridge Journal of Education, 30(2), 169-202.

Karataş, S. ve Ergin, S. (2014). Öğretmenlerin değerler eğitimi hakkındaki görüşleri: Bir durum çalışması. Journal of Educational Science, 2(2), 33-45. http://dergipark.gov.tr/download/article-file/148784 adresinden erişilmişitir.

Kart, M. (2017). Değerler eğitiminde bir model olarak abilik (Yüksek Lisans Tezi). Ahi Evran Üniversitesi Sosyal Bilimler Enstitüsü, Kırşehir. https://tez.yok.gov.tr sayfasından erişilmiştir.

Kurtdede Fidan, N. (2009). Öğretmen adaylarının değer öğretimine ilişkin görüşleri. Kuramsal Eğitimbilim, 2 (2), 1-18.

Meydan, H. (2014). Okulda değerler eğitiminin yeri ve değerler eğitimi yaklaşımları üzerine bir değerlendirme. Bülent Ecevit Üniversitesi Illabiyat Fakiiltesi Dergisi, 1(1), 93-108.

Oğuz, E. (2012). Öğretmen adaylarının değerler ve değerler eğitimine ilişkin görüşleri. Kuram ve Uygulamada Eğitim Bilimleri, 12 (2) [Ek Özel Say1], Bahar, 1309-1325.

Özdemir, Y.T., Boydak Özan, M. ve Akgün, M. (2017). Öğretmen görüşleriyle değerler eğitimi odaklı eğitim denetimi. Bartı Üniversitesi Ë̈itim Araştrmalar Dergisi, 1(1), 35-52.

Öztürk Demirbaş, Ç. ve Çelikkaya, T. (2012). Sosyal bilgiler öğretmen adaylarının programdaki değerlere ilişkin algisal farkindaliklar1. The Journal of Academic Social Science Studies (JASSS), 5(8), 415-427.

Pathania, A. (2011). Teachers' role in quality enhancement and value education. Academe, XIV(1), 19-28.

Rokeach, M, (1973). The nature of buman values. New York: The Free Press.

Schwartz, S. (1996). Values priorities and behavior: Applying a theory of integrated values systems. C. Seligman Etc. (Eds) Psychology of value: Ontorio symposium (pp. 1-24). New Jersey: Lawrance Erlbaum Associates.

Suriyachinnavar, K. (2016). Role of parents, guardians and teachers in value education. International Journal of Advance Research and Innovative Ideas in Education (IJARIIE), 1(2), 33-38.

Şahin, Y. (2017). Okul öncesi çocuklarda değerler eğitimi kapsammnda yardmmlașma ve dayamısma değerleri (Yüksek Lisans Tezi). Atatürk Üniversitesi Sosyal Bilimleri Enstitüsü, Erzurum. https://tez.yok.gov.tr sayfasından erişilmiştir.

Tay, B., Durmaz, F. Z. ve Şanal, M. (2013). Sosyal bilgiler dersi kapsamında öğrencilerin değer ve değerler eğitimine ilişkin görüşleri. GEFAD / GUJGEF, 33(1), 67-93.

Tunç, T. C. ve Ertem, İ.S. (2018). İlkokul öğretmenlerinin okuma tutum ve alışkanlıklarına ilişkin görüşleri. Socıal Mentality and Researcher Thinkers Journal, 4(14), 1037-1051.

Tural, A. ve Gürgil, F. (2012). Öğretmen adaylarının sosyal bilgiler öğretim programındaki değerlere ilişkin görüşleri. Türkiye Sosyal Arasttrmalar Dergisi, 16(2), 103-114.

Ulusoy, K. ve Dilmaç, B. (2012). Değerler Eğitimi. Ankara: Pegem. http://www.pegem.net/dosyalar/dokuman/05122012151624De\%C4\%9Ferler\%20e\%C4\%9Fitimi.pdf sayfasından erişilmiştir.

Yıldııı, A. ve Şimşek, H. (2016). Sosyal bilimlerde nitel araștırma yöntemleri. Ankara: Seçkin Yayıncllık. 


\section{EXTENDED ABSTRACT}

This study aims to find out the opinions of the primary school preservice teacher classroom training who have taken the Values Education course. The process of values education that starts in the family, goes on at school and continues throughout the life of an individual is given in a formal or informal way. First, the process of values education given in the family is important. However, the most important role in this process belongs to educational institutions/schools. This is because educational institutions/schools and therefore educators have great responsibilities to help children feel and gain values systematically and regularly in an interdisciplinary way.

Therefore, it is essential that preservice teacher classroom training express the objectives of the values education course, know the importance of the values education course, the learning-teaching process, and the strategies, methods and techniques that can be used in the course, are aware of the benefits of the course and make suggestions about the issues which they consider inadequate. In addition, individuals who have received values education are expected to act as role models with their behaviours and be a values education teacher. In this context, it is considered important to determine the opinions of preservice teacher classroom training on the values education course.

In the study that adopted a case study design, which is among qualitative research designs, data were collected through focus group interview technique. In the focus group interview form which was developed as a result of consulting two experts and two researchers to ensure the reliability and validity of the study, the questions were asked in the end, and in accordance with the qualitative research method, analyzes were made individually for each theme. In line with the opinions of two experts and two researchers, necessary adjustments were made, and the main focus group interviews were conducted. In addition, the researcher's education on the subject, expertise and qualitative research experiences were the factors that supported reliability. In order to collect the data, 8 preservice teacher classroom training , 5 female and 3 male, were interviewed. Students' responses were recorded on a tape recorder after taking their permission. Then, the data were analyzed by content analysis technique. In the first 6 weeks, the course was both theoretically and practically taught, predominantly theoretically, and in the next 8 weeks, it was given through activities that preservice teacher classroom training prepared by focusing on learning by doing and are based on active teaching methods and techniques. After the course period was completed, data were collected in 6 different focus group sessions for the six themes determined through expert opinions and were analyzed. Each question asked to the participant students was identified as a theme. Thus, six different themes were created: "objectives of the values education course", " the importance of the values education course", "the learning-teaching process", "methods and techniques used in the course", "benefits of the course" and "suggestions for the values education course".

In conclusion, the data related to the objectives of the values education course indicated that the participants stated them mostly as; 'Having knowledge about values', 'Understanding how values will be taught', 'Understanding the importance of activities in values education', Turning values into actions', 'Examining values in curriculums', 'Designing projects' and 'Giving values education through schoolfamily cooperation'. When the data about the importance of the values education course was examined, it was expressed as 'Values education course prepares students for life', 'It contributes to personality development', 'It teaches values education practically', 'It ensures living in harmony with society', 'It helps people be aware of values, internalize them/turn them into actions' and 'It teaches us how we should teach values'. When the data related to the learning and teaching process of the values education course were examined, it was revealed that the students stated that 'Firstly, the concepts related to values and values education are given theoretically', 'Then, activities are used in the values education process and the course is taught practically ' and 'Values education approaches (value inculcation, value explanation, value analysis, moral dilemma, action learning) are made use of in the learning-teaching process'. The data about the methods and techniques used in the values education course revealed 'Instruction', 'Presentation', 'Drama', 'Question-Answer', 'Brainstorming', 'Case study', 'Demonstration', 'Project', 'Trip-observation' and 'Educational game' as the methods and techniques. When the data about the benefits of the values education course were examined, it was seen that the preservice teacher classroom training mostly stated 'outcomes related to teaching profession', 'skill acquisition', 'outcomes related to social harmony, 'outcomes related to having knowledge about values' and 'affective outcomes'. When the suggestions about the values education course were examined, it was revealed that preservice teacher classroom training made suggestions for " The importance of the place and time of the course in the undergraduate program', 'Approaches, methods and techniques', 'Sample project examination', and 'School-family 
cooperation'. For the importance of the place and time of the course in the undergraduate program, two participants reported that students should be taught the values education course in the first years of the university. For the approaches, methods and techniques, the preservice teacher classroom training made suggestions about issues such as instruction, active teaching methods and techniques, internship application and being a role model. Under the theme of sample project examination, preservice teacher classroom training made suggestions about examining social responsibility projects carried out in our country or other countries, contacting the project executives and obtaining information. One participant stressed the need for school-family cooperation in values education.

Based on the data obtained in the research, the following suggestions can be made:

- The values education course should be taught compulsorily/electively as an independent course.

- Values education should be included in teacher education through a multidisciplinary or interdisciplinary approach.

- Values education and the education on how to teach values in teacher education should be designed in a way to be student-centered and based on learning by doing and active learning.

- Project-based learning can be grounded on in values education.

- The results of the study may be a guide for the institutions, organizations and persons who teach the values education course. 